\title{
MISIUNE ŞI/SAU CONVERTIRE: STRATEGII ALE DIPLOMAT,IEI BIZANTINE
}

Marius Telea*

\begin{abstract}
The religious element has always represented, inevitably, a feature of Byzantine diplomacy, offering it the instruments necessary for a fruitful dialogue with the pagan peoples in Eastern Europe. As one could notice, the classical policies of Constantinople involved different strategies, as well as exorbitant expenses, which did not always ensure long-term peace. On the other hand, religion operated at an abstract level, and in the medieval mentality, celebrating rituals such as baptism or marriage to a Byzantine Porphyrogenita established a stronger connection than the one constituted through peace treaties.
\end{abstract}

Although one cannot assert a decisive opinion concerning the spread of eastern Christianity, whether it was a purpose of the external Byzantine politics or just a means of obtaining peace, one thing is certain: preaching the Gospel represented a diplomatic practice with an immense power of persuasion.

These successes of the mission patronized by the Patriarchate of Constantinople, especially in the $\mathrm{IX}^{\text {th }}$ and $\mathrm{X}^{\text {th }}$ centuries show us that in this direction, the Byzantines were one step ahead of the Western world.

Keywords: mission, conversion, diplomacy, Slavs, barbarians

\section{Preliminarii}

Dacă ținem cont de faptul că Imperiul Bizantin s-a considerat până la capătul existenței sale continuatorul nu numai de iure, ci şi de facto al Imperiului Roman, nu ne va surprinde asemănarea

* PhD Associate Professor, "1 Decembrie 1918" University of Alba Iulia, (Faculty of Orthodox Theology), Romania. 
instituțiilor, a practicilor utilizate de ele, de-a lungul timpului. Mai mult, această continuitate va da principii generale în dreptul internaţional ce se vor perpetua chiar şi în epoca modernă. Între Antichitate şi Evul Mediu, Bizanțul a reprezentat în diplomație o verigă de legătură, una care a ştiut să adapteze, să modeleze cutume, să le transpună la cerințele concrete ale vremii.

Amplasamentul geografic al Constantinopolului a făcut din capitala Imperiului Bizantin un punct de atracție pentru barbarii din Asia şi din Occident. Popoarele migratoare din aceste regiuni erau impresionate de splendorile şi fastul Curții imperiale, iar Constantinopolul în calitatea sa de moştenitor al vechii Rome, respingea în principiu orice contact cu „Barbaria”. Prin calitatea pe care o dețineau, de popor ales şi singur credincios, bizantinii se considerau investiți cu un drept special în conducerea altor oameni.

Fiind un stat puternic centralizat, în care împăratul reprezenta vârful piramidei sociale, investit fiind de divinitate în această înaltă postură, toate demersurile diplomatice emanau de la el. În raporturile cu străinii, împărații nu pierdeau niciodată din vedere originea divină a fundamentului juridic al puterii lor, care se ridica deasupra tuturor oamenilor şi a statelor. Neavând egali pe pământ, ei considerau pe toți şefii de stat ca fiind subordonați puterii lor într-un fel anume. Ceea ce trebuie remarcat este că există, totuşi, o oarecare maleabilitate care se manifestă în tratarea diferențiată a şefilor de stat. În concepția oficială numai suveranul Bizanțului avea dreptul la titlul de basileus, el era singurul care emitea legi fiabile pentru întreaga lume ${ }^{1}$. Aceasta a rămas concepția, doctrina bizantină şi, de aici s-a născut ideea stabilirii unei ierarhii în protocolul adoptat față de diferite popoare.

Pe primul plan, pe un loc de onoare, se afla Persia cu care Imperiul Bizantin a avut multiple legături, când bune, când rele, încă de la începuturile existenței sale când Constantin cel Mare (306-337) a fost nevoit să țină cont de existența statului sassanid. Suveranii

\footnotetext{
${ }^{1}$ Louis Bréhier, Le monde byzantin, t. II: Les institutions de l'empire byzantin, Paris, Editions Albin Michel, 1970, p. 230.
} 
dinastiei instaurate în Partia în secolul al III-lea au căutat să restabilească puterea de altă dată a Persiei, de pe vremea dinastiei Achemenizilor (559-330 î. Hr.) şi au schimbat denumirea statului în regatul Noii Persii. Aici s-au adoptat obiceiurile şi procedura specifică statelor orientale, preluate nu numai de Bizanţ, ci şi de Imperiul de mai târziu, în general ${ }^{2}$. Cele două state - bizantin şi persan - s-au considerat singurele civilizate în faţa popoarelor barbare şi solidaritatea lor s-a materializat în măsuri comune luate pentru paza trecătorilor din Munții Caucaz împotriva invaziei popoarelor turanice spre Asia Mică (tratatele din 532 şi 562$)^{3}$.

Formulele de adresare oglindeau şi ele raporturile cordiale existente între cei doi suverani. Ei se tratau ca fraţi şi regele Persiei era numit basileus, de către împăratul bizantin într-o vreme când încă acest termen nu intrase în folosință. Regele Persiei îl numea pe împăratul roman Caesar iar lui îşi rezerva titlul de Şah-in-şah (basileus basileion) $^{4}$.

După perioada încordată în raporturile dintre cele două state, caracteristică sfârşitului domniei lui Constantin cel Mare (306-337), a urmat una de colaborare până în vremea împăratului Phocas (602610). In timpul lui Iustinian I (527-565) s-au semnat două ,păci eterne" (532 şi 562). Conducătorii celor două state îşi anunţau reciproc urcarea pe tron prin ambasade şi interveneau pentru protecția membrilor dinastiilor din care făceau parte. Împăratul Arcadius (395-408) 1-a numit pe regele persan Yazdegerd I (399420) tutore al fiului său Teodosie al II-lea (408-450) iar şahul Kavadh I (488-531) a fost gata să-1 determine pe Iustin I (518-527) să-l adopte pe fiul său, viitorul rege Chosroes I (531-579).

În anul 590, Chosroes al II-lea (590-628) a fost detronat de supuşii săi, dar un an mai târziu, împăratul Mauriciu (582-602) 1-a ajutat să-şi reocupe tronul. După ce şi Mauriciu a fost alungat de

\footnotetext{
${ }^{2}$ V. P. Potemkin et alii, Istoria diplomației, vol. I, ediție a doua, revăzută şi completată, îngrijirea ştiințifică a ediției româneşti: Petre Constantinescu-Iaşi, Bucureşti, Editura Ştiințifică, 1962, p. 75.

${ }^{3}$ Louis Bréhier, op. cit., p. 230.

${ }^{4}$ Ibidem, p. 517.
} 
Phocas, acest fapt a pus capăt definitiv bunelor relații dintre cele două state, determinând izbucnirea unui război de durată. El a început sub motivul răzbunării lui Mauriciu astfel că, în anul 604, Chosroes al II-lea a invadat Imperiul. Până în anul 610 acesta a ocupat aproape toate cetățile din Mesopotamia superioară ${ }^{5}$.

Perşii au dispărut de pe arena istoriei odată cu triumful islamismului în prima jumătate a secolului al VII-lea. La distrugerea statului lor a contribuit în mare măsură războiul victorios purtat de împăratul Heraclius I (610-641)6.

Pe ruinele sale au apărut, mai târziu, Emiratele arabe.

\section{Bizanțul şi popoarele slave}

În perioada secolelor IX-X misiunile bizantine au obținut o serie de succese, reuşind să aducă la creştinism mai multe popoare. Între acestea se remarcă marea masă slavă, câştigată la Hristos în a doua jumătate a secolului al IX-lea.

Uriaşa masă a populației slave care a invadat de la sfârşitul secolului al VI-lea atât Europa Centrală şi Răsăriteană cât şi Peninsula Balcanică, a provocat schimbări majore nu numai demografice sau politice, prin dispariţia unor structuri politice sau restrângerea granițelor Imperiului Bizantin, dar au modificat radical şi configurația creştină a acestor zone care fuseseră, în cea mai mare parte, creştinate de către Biserică.

Aşezarea populației slave în estul, centrul şi sud-estul Europei a constituit în a doua jumătate a primului mileniu, pentru întreaga lume creştină, dar mai ales pentru Bizanț, o mare provocare. O provocare existențială. De găsirea unor soluții de conviețuire cu populația slavă, organizată mai târziu în tinere state precum Moravia Mare, Bulgaria, Rusia kieveană, Serbia sau Polonia, depindea viitorul Imperiului, supraviețuirea lui chiar. Transformarea lor în

\footnotetext{
${ }^{5}$ Alain Ducellier, Michel Kaplan, Byzance. $I V$-e $-X V$-e siècles, Paris, 2003, p. 22; Paul Lemerle, Istoria Bizanţului, traducere de Nicolae-Şerban Tanaşoca, Bucureşti, Editura Teora, 1998, p. 74.

${ }^{6}$ Alain Ducellier, Michel Kaplan, op. cit., p. 22.
} 
aliaţi sau foederati ai Imperiului sau asimilarea lor, dacă era cu putință, şi, în acest context aducerea acestei populații la credința creştină, era o preocupare de prim ordin a lumii bizantine ${ }^{7}$. Astfel, după unii istorici, se poate vorbi de un proiect politico-misionar bizantin pentru lumea slavă, elaborat şi supravegheat cu mare atenție la Curtea constantinopolitană. În viziunea acestor istorici, excepționala lucrare a fraților Constantin-Chiril (826-869) şi Metodie (c. 815-885) în lumea slavă face parte integrantă din acel aşa-numit proiect slav sau chestiune slavă. În secolul al IX-lea mai ales, dar şi în următoarele, asistăm la o veritabilă evanghelizare a Europei, fiind aduse la credinţa creştină neamurile slave şi germanice, precum şi maghiarii, propovăduirea creştină întinzându-se mult peste vechile frontiere ale Imperiului Roman din timpul lui Constantin .

În virtutea concepției politice bizantine, a armoniei dintre „chestiunile dumnezeieşti” şi „treburile omeneşti” şi a „simfoniei" dintre cele două puteri lăsate de Dumnezeu pe pământ oamenilor, cea politică şi cea religioasă, puterea imperială şi Biserica, era obligatorie şi necesară cooperarea acestora şi în domeniul misiunii creştine. Împărații bizantini, după modelul lui Constantin cel Mare, autointitulat „cel intocmai cu Apostolii”, erau datori, potrivit ideologiei politice bizantine, să susțină şi să răspândească credința creştină atât prin acțiuni politice, sociale şi legislative, cât şi prin susținerea activității misionare şi filantropice a Bisericii. Pentru orice cetățean al statului era evident că sursele puterii țării lor erau Biserica dreptmăritoare şi suveranitatea universală a împăratului ${ }^{9}$. În această credință-concepție pe care o aveau bizantinii, care constituia baza ideologică şi justificarea morală a politicii interne şi externe a Bizanţului, putem identifica o triplă obârşie şi influență: a Romei, a elenismului şi a creştinismului. Ideea că Imperiul lor constituie

${ }^{7}$ Dimitri Obolensky, Un Commonwealth medieval: Bizanțul. Europa de Răsărit, 500-1453, traducere de Claudia Dimitriu, postfață de Nicolae-Şerban Tanaşoca, Bucureşti, Editura Corint, 2002, p. 303.

${ }^{8}$ Warren Treadgold, op. cit., p. 493.

${ }^{9}$ Cristian Ştefan, Misiunea creştină în Apus şi Răsărit (secolele V-X), ClujNapoca, Presa Universitară Clujeană, 2002, pp. 194-195. 
lumea civilizată era împrumutată de la romani, ai căror moştenitori exclusivi se declarau bizantinii, de aceea ei se şi numeau cu mândrie romei (rhomaioi). Atât de puternic era înrădăcinată această credință, încât era acceptată şi de cei mai învederați duşmani ai Bizanţului. Din această credință-concepție politică nezdruncinată, de la care ei nu s-au abătut, şi-au țesut planurile imperialiste țarul Simeon I cel Mare al Bulgariei (893-927), care se intitula ,împărat la bulgarilor şi romanilor", iar mai târziu, țarul Ştefan Uroş al IV-lea Duşan al Serbiei (c. 1308-1355), care se autointitula ,impărat al Serbiei şi Romaniei". În viziunea bizantinilor ei nu erau decât nişte uzurpatori ai adevăratului titlu pe care îl purta doar împăratul de la Constantinopol.

„Ce îndrăzneală să numeşti pe împăratul universal, unul şi singurul Nichephoros, cel mare, Augustul: «împărat al romanilor»! $\mathrm{O}$, cerule ! $\mathrm{O}$, pământule ! $\mathrm{O}$, mare ! Ce putem face cu aceşti nemernici şi criminali !"10 era exclamaţia plină de uimire şi revoltă a bizantinilor la auzul citirii de către legații papali a scrisorii trimise împăratului Nichifor al II-lea Phocas (963-969), în anul 968. În această ordine de idei tot ceea ce exista în afara acestei oikoumene bizantine era suspect, periculos, era dintr-o lume dezorganizată, fără Dumnezeu, o lume a întunericului şi a necredinței, lumea barbarilor. Această atitudine a bizantinilor faţă de aceste popoare fără de lege şi neînsemnate, care provenea din mediul elenistic, nu făcea decât să confirme şi să întărească teoria politică bizantină. Pentru că împăratul creştin al romanilor trebuia să aducă întreaga lume în oikoumen-ia creştină bizantină, existența însăşi a acestor barbari era o încălcare scandaloasă a suveranității lui. Prin însăşi calitatea sa de moştenitor al vechii Rome, Imperiul respingea orice contact $\mathrm{cu}$ Barbaria $^{11}$.

Neamurile străine, popoarele migratoare, deci barbarii, erau impresionați de splendorile şi fastul Curții imperiale şi al puterii

${ }^{10}$ Liutprand, Relatio de Legatione Constantinopolitana, LVII, pp. 200-201, apud Dimitri Obolensky, op. cit., nota 1, p. 299.

${ }^{11}$ Francis Dvornik, Les Slaves, Byzance et Rome au IX siècle, Paris, Librairie Ancienne Honoré Champion, 1926, p. 61. 
romeilor. Ei erau consideraţi a fi stăpâniţi în permanență de sentimentul geloziei şi când această ,lume obscură” a barbarilor ataca oikoumen-ia bizantină acest act era considerat o revoltă, sau o încercare de revoltă, împotriva stăpânirii de drept ${ }^{12}$. In antichitate, grecii numeau barbari neamurile care vorbeau limbi străine, neînţelese de ei şi a căror gândire şi mod de viaţă nu era compatibil cu cel grecesc. Mai târziu, acest termen a desemnat şi pe cei care trăiau în afara comunităţii de cultură greacă. $\mathrm{Cu}$ această semnificație au preluat şi bizantinii conceptul de barbar. Ceea ce îi deosebea pe romei de barbari nu era, în primul rând, limba sau etnicitatea, deşi de multe ori bizantinii disprețuiau celelalte limbi considerându-le rudimentare şi necioplite, ci aceeaşi credinţă şi supunerea faţă de acelaşi unic împărat. Pentru că imperialismul politic şi cel religios mergeau mână în mână şi se susțineau unul pe celălalt, termenul de barbar echivala acum cu cel de păgân. Păgânul care accepta credința creştină ortodoxă accepta implicit şi supunerea faţă de împărat, deci înceta teoretic să mai fie barbar.

Al treilea element care stătea la baza oikoumen-ei bizantine provenea din tradiția iudeo-creştină. Bizantinii credeau că ,orice stăpânire este de la Dumnezeu" şi că face parte din planul universal al lui Dumnezeu, fiind strâns legată de istoria mântuirii omului. Romeii erau cei care prin Constantin cel Mare au fost chemaţi să slujească lui Hristos şi să împărtăşească învățătura lui Hristos popoarelor pământului. Astfel, pax romana a devenit şi înseamnă acelaşi lucru cu pax christiana. Pentru aceasta, politica externă a Imperiului a devenit strâns legată de activitatea misionară a Bisericii $^{13}$. Alianța dintre Biserică şi Stat, în afara graniţelor, a condus adeseori la identificarea de către barbari a intereselor politice ale Imperiului cu soarta creştinismului. În foarte multe situaţii conducătorii necreştini i-au persecutat pe creştini, nu numai din fanatism, ci şi pentru că îi suspectau a fi agenţi ai împăratului.

\footnotetext{
${ }^{12}$ Emanoil Băbuş, Introducere în Istoria Bisericească Universală, Bucureşti, Editura Sophia, 2003, p. 229.

${ }^{13}$ Dimitri Obolensky, op. cit., p. 301.
} 
Aceasta a fost una din cauzele care a făcut ca creştinismul să pătrundă atât de puțin în rândul popoarelor musulmane care veneau din Răsărit. Această alianță foarte puternică între Stat şi Biserică, care însemna împletirea operei misionare cu scopurile politice externe ale Imperiului, a fost uneori o piedică pentru că unele popoare erau pătrunse de propriile lor tradiții religioase şi de teama pierderii lor refuzau protectoratul bizantin, iar altele țineau prea mult la independența lor şi pentru aceasta erau refractare la primirea credinței creştine ${ }^{14}$.

Aceste principii de bază despre care am pomenit, cele trei elemente care stăteau la baza teoriei politice bizantine, trebuiau aplicate în politica externă şi constau în: a apăra hotarele Imperiului distrugând din faşă atacurile barbarilor şi a extinde cât mai mult influența politică şi culturală a Bizanțului prin crearea unor state clientelare a căror loialitate putea fi garantată doar de acceptarea credinței creştine şi a suveranităţii împăratului ${ }^{15}$.

De-a lungul a două sute de ani, aproximativ între anii 650-850, opera misionară a Bizanțului a suferit un inevitabil regres din cauza luptei continue împotriva arabilor care invadaseră posesiunile din nord şi din sud ale Imperiului, a năvălirii şi ocupării aproape în întregime a Peninsulei Balcanice de către avaro-slavi, precum şi din cauza controversei iconoclaste. Toate acestea au obligat Imperiul săşi folosească toate energiile într-o luptă pe viață şi pe moarte cu duşmanii săi şi a epuizat resursele spirituale ale Bisericii din cauza persecuției iconoclaste, colmatând şi îngreunând politica externă a Bizanțului.

Secolul al IX-lea a fost secolul renaşterii universalismului bizantin, care era oricum idealul împăraților din Constantinopol, al reinstituirii autorităţii bizantine în Orient. Arabii nu vor mai amenința de acum niciodată Constantinopolul, aceasta şi datorită întăririi acestuia în provinciile balcanice, unde a reuşit să depăşească dezordinea provocată de instalarea populației slave în teritoriul său şi

\footnotetext{
${ }^{14}$ Cristian Ştefan, op. cit., p. 196.

${ }^{15}$ Dimitri Obolensky, op. cit., p. 301.
} 
să-şi restabilească supremația ${ }^{16}$. În secolele IX-X misiunile bizantine au obținut excepționale succese, între acestea, la loc de frunte remarcându-se convertirea celei mai mari părți a slavilor.

Slavii au apărut destul de devreme în viața Imperiului Bizantin. Dacă până la sfârşitul secolului al VI-lea eu au putut fi respinşi, începând cu secolul al VII-lea, ei vor trece limes-ul Dunării şi vor invada provinciile bizantine, aşa cum arătat mai sus. Până în secolul al IX-lea, când se vor converti, ei au intrat deja în contact cu religia creştină prin populația greco-romană rămasă în enclavele bizantine necucerite din Balcani: Tesalonic, Atena, Patras, Ragusa, Split, Zadar $^{17}$.

O parte a triburilor slave din Balcani vor cunoaşte creştinismul încă dinainte de secolul al IX-lea, dar convertirile erau sporadice iar difuzarea creştinismului nu era legată de la început de Botez ${ }^{18}$. Botezul era considerat punctul culminant al procesului misionar, fiind urmat de o serie de măsuri care priveau mai mult organizarea bisericească. Conform concepției epocii modelul lui Constantin cel Mare era preluat de majoritatea suveranilor care se converteau. Convertirea suveranului însemna şi convertirea supuşilor săi ${ }^{19}$. Doar prin îmbrăţiş̧area creştinismului de către un principe şi împreună cu el de către toți supuşii lui, permitea admiterea acelui stat în ierarhia statelor creştine. Procesul de convertire al slavilor a fost destul de lent, el fiind desăvârşit de frații Constantin-Chiril şi Metodie ${ }^{20}$. Mult timp slavii au fost priviţi ca nişte simpli năvălitori barbari de care trebuia să se ocupe administrația imperială pentru îndepărtarea şi

${ }^{16}$ Hélène Ahrweiler, Ideologia politică a Imperiului bizantin, traducere de Cristina Jinga, postfață de Nicolae-Şerban Tanaşoca, Bucureşti, Editura Corint, 2002, pp. 36-37.

${ }^{17}$ Keneth M. Setton, The Bulgars in the Balkans and the Occupation of Corinth in the Seventh Century, în „Speculum”, vol. 25, 1950, nr. 4, p. 510.

${ }^{18}$ Francis Dvornik, Slavii în istoria şi civilizația europeană, traducere de Diana Stanciu, Bucureşti, Editura All Educațional, 2001, p. 630.

${ }^{19}$ Alain Ducellier, Byzance et le monde orthodoxe, Paris, Armand Collin, 1986, pp. 229-233.

${ }^{20}$ Emanoil Băbuş, op. cit., p. 231. 
pedepsirea lor. Dar, din momentul în care aceştia s-au stabilizat, creându-şi mici formaţiuni politice, aşa-numitele slavinii sau sclavinii iar mai târziu şi-au creat adevărate state slave sau care au devenit slave - cum ar fi Bulgaria şi Rusia, într-o anumită măsură ei au devenit un subiect al politicii externe şi al diplomației bizantine şi trebuiau aduşi în sfera culturală şi spirituală a Imperiului Bizantin.

\section{Convertirea religioasă ca practică a diplomației bizantine}

Pentru început, trebuie să menționăm faptul că utilizarea termenului ,diplomație”, definind întregul set de practici utilizate de bizantini pentru a-şi negocia poziția în raport cu alte puteri, este anacronică, deoarece cuvântul a apărut târziu, în opera călugărului benedictin Jean Mabillon, „De re diplomatica” (1681), în care se descriu metodele de examinare a documentelor cu scopul de a le stabili originea, înțelesul şi autenticitatea. Mai târziu, diplomația lui J. Mabillon a dobândit definiția actuală, care acoperă toate formele de comunicare între state, cu precădere prin intermediul ambasadorilor trimişi în capitale străine, aspect care presupune existenţa unui secretariat al afacerilor externe, menit să preia şi să reacționeze la rapoartele trimise de ambasadori ${ }^{21}$.

În jurul diplomației bizantine s-au format numeroase mituri, câteva epitete insinuându-se, cu predilecție, în descrierea sa: vicleană, perfidă şi pierdută într-un labirint de uneltiri. Pentru fiecare dintre aceste caracteristici există, totuşi, unele baze ancorate în adevărul istoric ${ }^{22}$. În acelaşi timp, atribute ca eficacitatea, sagacitatea

21 Edward N. Luttwak, The Grand Strategy of the Byzantine Empire, Cambridge, Mass., London, The Belknap Press of Harvard University Press, 2009 , p. 95.

${ }^{22}$ Ibidem. 
şi ingeniozitatea au fost, de asemenea, uzate în mod curent de istoricii care au studiat diplomația bizantină ${ }^{23}$.

$\mathrm{O}$ invenție provenită din spațiul italian renascentist, unde micile state din peninsulă aveau reprezentanți în fiecare centru politic italian, diplomația practicată în acest areal răspundea nevoilor unor state nesigure, ale căror duşmani se aflau la distanțe foarte scurte, fiind necesare informații privind fiecare schimbare de atitudine ${ }^{24}$. Circumstanțele Imperiului Bizantin erau altele, deoarece aliații şi duşmanii acestuia nu se aflau în imediata apropiere a Bizanțului, care trebuia să trateze cu puteri situate la mari distanțe, cu care nu aveau în comun nici limba, nici obiceiurile ${ }^{25}$.

Rolul diplomației era esențial pentru Imperiul Bizantin, deoarece completa $\mathrm{cu}$ succes activitatea militară. $\mathrm{Cu}$ ajutorul diplomaților, bizantinii erau capabili să stârnească certuri în rândul liderilor armatelor inamice, amânau negocierile până în punctul în care trupele inamice rămâneau fără alimente sau erau decimate de boli, ori îi convingeau pe adversari de iminente atacuri ale unor aliați ai Imperiului. Fără îndoială, acestea, dar şi alte practici diplomatice, au constituit un arsenal de arme non-militare aflat, în permanență, la dispoziția conducerii imperiale, ajutând Bizanțul să respingă numeroase pericole care i-au pus existenţa în pericol ${ }^{26}$. De cele mai multe ori, însă, diplomația a reprezentat principala armă a Imperiului în privința politicii sale externe. Caracteristica distinctivă a strategiei bizantine, de la începutul Imperiului până la prăbuşirea sa, a fost accentuarea artei persuasiunii în relațiile cu forțele străine. Oferirea de cadouri sau a tributului era o practică veche, preferabilă războaielor scumpe. Faptul că Imperiul Bizantin prefera aurul în locul ascuțişului sabiei, pentru a-şi asigura pacea, este una dintre

23 Alexander Kazhdan, The Notion of Byzantine Diplomacy, în Jonathan Shepard, Simon Franklin (Eds.), Byzantine Diplomacy, Aldershot, Variorum Reprints, 1992, p. 7.

${ }^{24}$ Edward N. Luttwak, op. cit., p. 95.

${ }^{25}$ Ibidem, p. 96.

${ }^{26}$ John F. Haldon, Warfare, State and Society in the Byzantine World, 5651204, UCL Press, London, 1999, p. 64. 
falsele distincții pe care unii istorici le-au descris în comparația cu Imperiul Roman. Documentele au arătat contrariul, această practică reliefând o continuitate între Imperiul Roman şi Bizanţ, romanii preferând, încă din perioada glorioasă a lui Octavian Augustus, în secolul I, până la Marcus Aurelius, în secolul al II-lea, să îşi cumpere duşmanii decât să lupte împotriva acestora, dacă situația permitea o astfel de rezolvare ${ }^{27}$. Accentul pus de scriitorii şi guvernanţii bizantini pe utilizarea eficientă şi inteligentă a diplomației nu rezulta numai din cultura bizantină influențată de dogma creștină, care respingea vărsarea de sânge, ci şi dintr-o dependenţă insurmontabilă a aparatului militar de mijloacele diplomatice ${ }^{28}$.

La fel ca multe alte instituții ale puterii bizantine, diplomația era extrem de centralizată, condusă din capitală şi aplicată de funcționari imperiali, care primeau, în schimbul serviciilor prestate, titluri înalte, recompense valoroase şi privilegii variate ${ }^{29}$. Tratamentul favorabil de care beneficiau diplomații bizantini se datora misiunilor cu un grad înalt de risc pe care aceştia erau nevoiți să le îndeplinească. Navigația pe Marea Mediterană şi călătoriile în teritoriile care nu aveau granițe cu Imperiul erau înțesate de obstacole. Deoarece logica dicta că cele mai bune alianțe erau cele încheiate cu duşmanii vecinilor inamici, trimişii Constantinopolului aveau parte de primiri ostile în teritoriile vizate de aceste alianţe. În plus, în teritoriile slab guvernate (state eşuate, în termeni moderni), solii şi escorta acestora trebuiau să respingă uneori triburi de o barbarie feroce ${ }^{30 .}$

Diplomații bizantini erau aleşi pe baza reputației privind religiozitatea, trecutul lor nu trebuia să fie pătat de nici o acuzație de comitere a unei infracțiuni, trebuiau să dovedească inteligenţă şi spirit civic, manifestat prin acceptarea posibilităţii de a-şi risca viaţa pentru stat. $\mathrm{Cu}$ toate acestea, misiunile erau acceptate benevol, nu în

\footnotetext{
${ }^{27}$ Edward N. Luttwak, op. cit., pp. 111-112.

${ }^{28}$ John F. Haldon, op. cit., pp. 38-39.

${ }^{29}$ Alexander Kazhdan, op. cit., p. 9.

${ }^{30}$ Edward N. Lutwak, op. cit., p. 101.
} 
urma unei coerciții, solii trecând, în prealabil, printr-o perioadă de testare şi învățare ${ }^{31}$.

Aspectul religios al diplomației bizantine a fost evidențiat de numeroşi cercetători ai acestei probleme, reliefând rolul Bisericii în diplomație, acționând $\mathrm{ca}$ instrument al puterii imperiale. $\mathrm{Cu}$ toate acestea, nu se poate emite o opinie fermă în privința răspândirii creştinismului dinspre Constantinopol, dacă aceasta a fost un scop al politicii externe bizantine sau doar un mijloc de obținere a păcii ${ }^{32}$. Un fapt este cert: propovăduirea Evangheliei a reprezentat o practică diplomatică cu o putere de persuasiune imensă $\breve{a}^{33}$.

Biserica, gata oricând, în ceea ce o privea, să susțină efortul expansionist al statului, care asigura lărgirea jurisdicției sale, a condus o operă misionară în rândul popoarelor din Balcani, de la Marea Neagră şi chiar din Europa centrală. Patriarhul Fotie (858-867, 877-886) se mândrea cu acest efort misionar în enciclica adresată celorlalți patriarhi (867), iar papa Nicolae I (858-867) se va îngriji ca evanghelizarea popoarelor să dea rezultatele scontate; în epistolele sale către clericii din Chersones şi din Alania, el preciza atitudinea pe care Biserica trebuia să o adopte față de popoarele insuficient creştinate. Un fapt interesant de notat este că observațiile lui Fotie nu erau scutite de tenta preocupărilor politice, ci erau chiar supuse intereselor statului - interese politice şi diplomatice pe care Biserica le servea prin opera sa misionară. Creştinarea bulgarilor şi, mai târziu, a ruşilor a constituit marele succes al acestei politici care îi îngăduise Bizanțului să îşi extindă, de-a lungul timpului, influența spirituală, artistică şi politică asupra lumii slave, pe o arie care depăşea cu mult granițele Imperiului ${ }^{34}$.

Convertirea bulgarilor nu s-a produs brusc, ci pe parcursul unei perioade mai lungi de timp, fiind uşurată de contactele dese ale bulgarilor cu creştinismul. În Peninsula Balcanică, bulgarii se aflau într-o stare de izolare, iar liderul acestora, țarul Boris I (852-889), era

${ }^{31}$ Ibidem.

${ }^{32}$ Alexander Kazhdan, op. cit., p. 8.

${ }^{33}$ Edward N. Luwak, op. cit., p. 113.

${ }^{34}$ Hélène Ahrweiler, op. cit., p. 43. 
conştient de importanţa aderării la ideile creştine, însă nu avea încrederea necesară pentru a-şi lega destinul de patriarhul din Constantinopol, iar din acest motiv, primele tratative în direcția creştinării au fost încercate în vest. În acest sens, Boris a încheiat un tratat cu regele franc Ludovic al II-lea Germanicul (855-875), în anul 862, în anul următor papa fiind notificat în privința planurilor țarului Boris I, însă proiectele liderului bulgar au fost deviate de dezlănțuirea unei foamete care i-a determinat pe bulgari să pătrundă în teritoriul bizantin pentru a tempera acuta criză internă. Acțiunile lor au stârnit represalii din partea Imperiului, atacurile venind atât pe uscat, cât şi pe mare, bulgarii nefiind capabili să opună rezistență. Impăratul Mihail al III-lea (842-867) şi influentul cezar Bardas († 866) urmăriseră încercările țarului Boris I de a adera la creştinism prin intermediul Occidentului, astfel că pacea a fost oferită în schimbul creştinării prin medierea patriarhului de la Constantinopol $^{35}$.

T,arul Boris I a acceptat propunerea, neavând nici o altă opțiune la îndemână. Toate sursele despre convertirea bulgarilor tind să evidențieze minunea intervenției divine, rolul foametei, calitățile diplomatice excepționale ale împăratului şi ale anturajului lui Boris, dar nici o sursă nu menţionează existența unor misionari bizantini. Probabil că Boris nu ar fi acceptat creştinismul pe filiera constantinopolitană dacă nu ar fi existat circumstanțe excepționale. Cert este că acțiunea bizantină nu a fost premeditată, fapt recunoscut şi de Fotie, care numise creştinarea bulgarilor „improbabilă" ${ }^{\prime 36}$. Un alt fapt semnificativ este că mai mulți autori bizantini, scriind în secolul următor, au afirmat că bulgarii, devenind creştini, au recunoscut suveranitatea împăratului bizantin, afirmație menţionată şi de papa Nicolae I într-o scrisoare adresată lui Hincmar,

${ }^{35}$ Nicolae Bănescu, Istoria Imperiului Bizantin, vol. II: 610 d. Hr.-1081 d. Hr., ediție îngrijită de Tudor Teoteoi, București, Editura Anastasia, 2003, pp. 248249.

${ }^{36}$ Sergey A. Ivanov, „Religious Missions”, în Jonathan Shepard (ed.), The Cambridge History of the Byzantine Empire (c. 500-1492), Cambridge, Cambridge University Press, 2008, p. 318. 
arhiepiscop de Reims. Această pretenție se acordă pe deplin cu o dogmă de bază din filozofia politică bizantină, potrivit căreia un popor, după ce a acceptat credința creştină a Imperiului, devenea supus autorității împăratului, considerat a fi singurul suveran legitim al lumii creştine ${ }^{37}$. Un semn al acestei subordonări era relaţia spirituală care îl lega pe liderul poporului proaspăt convertit de persoana împăratului, iar gradul acestei relaţii, care varia de la un popor la altul, definea rangul exact ocupat de acel popor în comunitatea creştină condusă de împărat. Situaţia Bulgariei a fost exprimată, în mod simbolic, de rangul conferit țarului Boris I la botezul său, unde naş i-a fost împăratul. Botezat Mihail, Boris a devenit fiul spiritual al împăratului ${ }^{38}$.

Faptul că bulgarii au primit botezul prin mâinile clerului grec a contribuit la sporirea prestigiului şi influenței Imperiului Bizantin în Peninsula Balcanică. T,arul Boris I a dorit să păstreze dreptul de călăuzire a vieții spirituale a bulgarilor şi s-a temut, de asemenea, că regatul său ar putea deveni dependent politic de Bizanţ, motiv care 1a determinat să apeleze din nou la papa Nicolae I, rugându-l să trimită preoți latini în Bulgaria ${ }^{39}$. Din această situaţie, Boris a urmărit, mai degrabă, obținerea unor câştiguri politice, fiind conştient de avantajul pe care îl putea obține într-o înfruntare dintre Roma şi Constantinopol, conducătorul bulgarilor continuând să oscileze între cele două poluri ale puterii spirituale. Această rivalitate romanobizantină pentru dobândirea creştinismului bulgar s-a aflat la originea a ceea ce s-a numit schisma lui Fotie. În aceste condiții, sinodul local din Constantinopol (879-880), recunoscând legitimitatea lui Fotie, a proclamat, însă, dependența Bulgariei față de Roma, dar bulgarii vor rămâne ortodocşi $i^{40}$. Mult mai important, din perspectiva diplomaţiei bizantine, este faptul că evenimentul convertirii lui Boris a pacificat raporturile dintre regatul său şi Bizanț. În cele din urmă, fiii săi au

${ }^{37}$ Dimitri Obolensky, op. cit., p. 101.

${ }^{38}$ Ibidem.

${ }^{39}$ A. A. Vasiliev, op. cit., p. 292.

${ }^{40}$ Alain Ducellier, Bizantinii. Istorie și cultură, traducerea de Simona Nicolae, București, Editura Teora, 1997, p. 61. 
ajuns la Constantinopol, unde au fost educați, asimilând ideologia imperială. Simeon (893-927), al doilea fiu al lui Boris I, a urcat pe tronul bulgar şi a intrat în conflict cu Bizanțul, urmărind să pună stăpânire pe Constantinopol şi să întemeieze un imperiu romanobulgar, dar ofensiva sa a fost respinsă în fața zidurilor Constantinopolului, iar moartea sa, în anul 927, a fost urmată de aproximativ şaizeci de ani de pace ${ }^{41}$. Acest eveniment demonstrează eficiența utilizării elementului religios în raporturile diplomatice ale imperiului. $\mathrm{Cu}$ siguranță, bulgarii nu au cunoscut o revoluție spirituală imediată, dovadă fiind reacția pe care elita conducătoare a avut-o împotriva deciziei lui Boris, militând pentru restaurarea păgânismului ${ }^{42}$, însă beneficiile directe pentru Statul bizantin şi Biserică au venit imediat, ambele extinzându-şi influența în Balcani. În cele din urmă, creştinarea poporului bulgar s-a produs, de la vârf spre bază, iar Biserica a fost organizată de clericii din Bizanț şi, cu toate că Bulgaria a continuat să fie independentă, ea a rămas definitiv în sfera de influență a Imperiului Bizantin, convertirea bulgarilor constituind una dintre cele mai importante realizări politice şi culturale ale Bizanțului ${ }^{43}$.

Datorită bisericilor impozante, a liturghiilor tulburătoare, a corurilor melodioase, a doctrinei bine formulată şi a clerului educat, Biserica bizantină s-a arătat ca o oportunitate atrăgătoare în privința convertirii. Pentru misionarii bizantini care răspândeau cuvântul sfânt departe de Constantinopol, aspectul politic al misiunii lor nu era important, scopul lor fiind salvarea sufletelor păgânilor, dar, în subsidiar, se producea şi o recrutare a posibililor aliaţi ${ }^{44}$. Acest fapt s-

${ }^{41}$ Michel Kaplan, Bizanț, traducere din limba franceză de Ion Doru Barna, București, Editura Nemira, f. a. (2010), p. 28.

${ }^{42}$ Dimitri Obolensky, op. cit., p. 101. Este vorba despre o revoltă generală instigată de conducătorii clanurilor vechi bulgărești, scopul fiind asasinarea lui Boris și revenirea la vechile credințe. Revolta a fost pe punctul de a reuși, însă Boris a fost capabil să formeze un grup de partizani credincioși și a zdrobit revolta printr-o lovitură sângeroasă.

${ }^{43}$ Timothy E. Gregory, op. cit., p. 216.

${ }^{44}$ Edward N. Lutwak, op. cit., p. 113. 
a petrecut în cazul convertirii ruşilor. Odată petrecut faptul, colaborarea sau chiar alianța cu Bizanțul era mult mai uşor acceptată, chiar şi atunci când existau diferende cu împăratul, autoritatea patriarhului fiind mai greu de ignorat, cu toate că aceștia erau numiți de împărat. Un exemplu sugestiv provine din perioada când Bizanțul rămăsese un oraş-stat, însă ruşii au acceptat, fără opoziție, îndrumarea unor patriarhi renumiți precum Filotei Kokkinos (1364$1376)^{45}$.

Atragerea ruşilor spre credința ortodoxă s-a petrecut, la fel ca şi în cazul bulgarilor, cu multă lentoare, fiind aplicată tot ca urmare a unor evenimente care necesitau o intervenție diplomatică din partea bizantinilor. De la expediția lui cneazului Oleg (879-912) împotriva Constantinopolului, în anul 907, un eveniment prea puțin menționat în sursele medievale, raporturile dintre Bizanț şi cnezatele ruseşti, fie de ostilitate, fie de prietenie, s-au înmulțit considerabil. Începând cu secolul al X-lea, armatele bizantine au inclus importante corpuri de mercenari ruşi. Totuşi, în timpul domniei lui Roman I Lecapenos (920-944), în anii 941 şi 944, Constantinopolul a fost atacat din nou, cneazul Igor, întorcându-se la Kiev doar după semnarea unui tratat de pace. De abia în timpul lui Vasile al II-lea Macedoneanul (976-1025) a fost găsită o soluție eficientă pentru rezolvarea problemele Imperiului cu Rusia ${ }^{46}$. Înainte de anul 989, cu excepția perioadei când Olga a condus Kievul, după ce devenise creştină (957-969), cnejii ruşi se considerau total independenţi în toate sensurile iar bizantinii nu aveau pretenții la vreo jurisdicție, ideală sau reală, asupra Rusiei păgâne. Convertirea Olgăi şi faptul că ea a recunoscut suveranitatea universală a împăratului au făcut ca Rusia să devină membră a comunităţii creştine, dar după moartea ei elitele din Kiev au adoptat din nou păgânismul, acompaniat de o politică antibizantină $^{47}$. Soluţia creştinării ruşilor a venit într-un context de

${ }^{45}$ Ibidem.

${ }^{46}$ Paul Lemerle, Istoria Bizantului, traducerea de Nicolae Șerban-Tanașoca, București, Editura Teora, 1998.

${ }^{47}$ Dimitri Obolensky, op. cit., p. 223. 
criză pentru Imperiu. În Balcani a izbucnit o răscoală împotriva puterii bizantine, condusă de cei patru fii ai guvernatorului provinciei Macedonia, comitele Nicola, numiţi Kometopouloi. Cel mai tânăr dintre aceştia, Samuel (987-1014), a preluat conducerea şi a fost iniţiatorul unei perioade de înflorire a Bulgariei, considerându-se descendentul direct al statului creat de țarul Simeon cu aproximativ o sută cincizeci de ani mai devreme. $\mathrm{Cu}$ un an înainte de a prelua singur puterea, Samuel a reuşit să-şi extindă teritoriul spre sud cucerind, în anii 985/986, Larissa şi ocupând cea mai mare parte a Tessaliei. Împăratul Vasile al II-lea a contraatacat, dar trupele sale au fost înfrânte la Poarta lui Traian. În contextul acestui eşec, aristocrația bizantină s-a revoltat, cum o mai făcuse şi atunci când tânărul Vasile al II-lea s-a declarat apt să îşi exercite puterea de unul singur. Bardas Skleros (976-979) s-a întors din exil şi a încercat să obțină controlul puterii imperiale, dar s-a lovit de opoziția lui Bardas Phocas (987-989), care a devenit principalul pretendent la titlul de împărat ${ }^{48}$.

Aceasta este situația care l-a determinat pe Vasile al II-lea să apeleze la ajutorul marelui cneaz rus Vladimir I Sviastolavici (9781015), care a trimis o armată alcătuită din 6.000 de războinici, probabil vikingi, care au luptat sub comanda împăratului, învingându-l pe Bardas Phocas. Bardas Skleros s-a revoltat din nou, dar a fost, la rândul său, învins. În anul 989, după numeroase incidente cu aristocrația bizantină, împăratul Vasile al II-lea a devenit conducătorul absolut al Imperiului ${ }^{49}$. Drept răsplată pentru ajutorul acordat, bazileul i-a oferit lui Vladimir I mâna surorii sale, Ana. Aceasta era o ofertă extraordinară, deoarece nici un conducător păgân şi destul puțini dintre cei creştini se căsătoriseră vreodată cu o prințesă bizantină ${ }^{50}$. Condiția pentru înfăptuirea acestui act era ca

\footnotetext{
${ }^{48}$ Timothy E. Gregory, op. cit., p. 243.

${ }^{49}$ Ibidem.

${ }^{50}$ Warren Treadgold, $O$ istorie a statului și societătiii bizantine, vol. I: (2841025), traducere de Mihai-Eugen Avădanei, ediție îngrijită de Victor Spinei și Bogdan-Petru Maleon, prefață de Victor Spinei, Iași, Institutul European, 2004, p. 524.
} 
Vladimir I şi poporul său să accepte botezul din partea Constantinopolului. Din punct de vedere diplomatic, decizia lui Vasile al II-lea a reprezentat un mare compromis, deoarece Ana era o porphyrogenetă, iar actul semnifica prețuirea uriaşă pe care acesta o avea faţă de alianţa cu ruşii, în vreme ce pentru Vladimir I gestul avea o conotație la fel de pozitivă, convins fiind că viitorul țării sale depindea de alianța cu bizantinii ${ }^{51}$. Prin căsătorie, el a devenit ginere al împăratului, iar prin botez, cu ocazia căruia a primit numele de Vasile, a devenit, la fel ca țarul Boris I, cu mai bine de o sută de ani mai devreme, fiul spiritual al împăratului. Statutul marelui cneaz Vladimir I în ierarhia conducătorilor creştini era similar cu cel al lui Petru al Bulgariei, din anul 927, dar cu o oarecare întâietate datorită căsătoriei cu Ana, o porphyrogenetă. Istoricul britanic de origine rusă Dimitri Obolensky este de părere că nu este nici o îndoială că Rusiei i s-a acordat, după anul 989, un statut înalt în comunitatea statelor Europei de Răsărit. Deşi aflat pe o poziție foarte înaltă, totuşi Rusia era subordonată Imperiului Bizantin şi, cu toate că marele cneaz Vladimir I şi urmaşii săi din Evul Mediu au fost complet independenți în chestiunile de politică internă, ea l-au recunoscut pe basileu drept liderul comunității creştine ortodoxe, având prin dreptul divin o jurisdicție meta-politică asupra Rusiei ${ }^{52}$.

Prin convertirea marelui cneaz Vladimir I la creştinism s-a încheiat o etapă a relațiilor ruso-bizantine dominată de neîncredere reciprocă, ruşii reprezentând un pericol important pentru securitatea frontierelor Imperiului. Convertirea nu a reprezentat o ruptură definitivă de acest trecut, însă a permis ca relațiile dintre cele două entități să se coaguleze pe o bază solidă, înlesnind dialogul dintre cele două puteri. Convertirile bulgarilor şi ruşilor au lărgit arealul creştinismului răsăritean, oferind Imperiului o poziţie centrală în acest spațiu, evitând o izolare dificilă într-o parte a lumii populată de musulmani, păgâni şi eretici. Bizantinii au creat în acest spațiu, un

${ }^{51}$ Timothy E. Gregory, op. cit., p. 243.

${ }^{52}$ Dimitri Obolensky, op. cit., pp. 223-224. 
Commonwealth bizantin ortodox, alcătuit din câteva State şi Biserici autocefale, lărgind sfera culturală a Bizanțului.

Deşi misionarii Constantinopolului nu considerau că acțiunile lor aveau un caracter diplomatic, fiind ghidați mai degrabă de o credință puternică şi de exemplul primilor Apostoli, aceştia au reprezentat o importantă punte de comunicare între puterea imperială şi populațiile păgâne.

\section{Concluzii}

Din cele expuse remarcăm astfel, faptul că elementul religios a constituit o particularitate a diplomației bizantine, oferindu-i instrumentele necesare stabilirii unui dialog fructuos cu popoarele păgâne din estul Europei. După cum s-a putut observa, tacticile clasice ale diplomației constantinopolitane presupuneau strategii diferite precum şi cheltuieli exorbitante, care nu asigurau întotdeauna o pace de lungă durată. Pe de altă parte, religia opera la un nivel abstract, iar în ansamblul mentalităților medievale, oficierea unor ritualuri precum botezul sau căsătoria cu o porphyrogenetă stabileau o legătură mai puternică decât cea constituită prin intermediul unor tratate de pace.

Aceste reuşite ale misionarismului patronat de Patriarhia de la Constantinopol îndeosebi în secolele IX-X, ne arată că în această direcție bizantinii au fost cu un pas înaintea apusenilor, fie ei romani sau franco-bavarezi. Disputei pentru hegemonia bisericească asupra neamurilor de limbă slavă dintre Roma şi Constantinopol, le-au căzut însă, indirect, victime, frații Constantin-Chiril şi Metodie, împreună cu alți ucenici ai lor. În loc să fie sprijiniţi în lupta împotriva păgânismului, ei au fost persecutați, un rol de seamă având şi interesul politic. 


\section{Bibliografie}

1. Ahrweiler, Hélène, Ideologia politică a Imperiului bizantin, traducere de Cristina Jinga, postfaţă de Nicolae-Şerban Tanaşoca, Bucureşti, Editura Corint, 2002.

2. Băbuş, Emanoil, Introducere în Istoria Bisericească Universală, Bucureşti, Editura Sophia, 2003.

3. Bănescu, Nicolae, Istoria Imperiului Bizantin, vol. II: 610 d. Hr.-1081 d. $H r$., ediție îngrijită de Tudor Teoteoi, București, Editura Anastasia, 2003.

4. Bréhier, Louis, Le monde byzantin, t. II: Les institutions de l'empire byzantin, Paris, Editions Albin Michel, 1970.

5. Ducellier, Alain, Bizantinii. Istorie şi cultură, traducerea de Simona Nicolae, Bucureşti, Editura Teora, 1997.

6. Ducellier, Alain, Byzance et le monde orthodoxe, Paris, Armand Collin, 1986.

7. Ducellier, Alain, Michel Kaplan, Byzance. $I V-e-X V$-e siècles, Paris, 2003.

8. Dvornik, Francis, Les Slaves, Byzance et Rome au IX siècle, Paris, Librairie Ancienne Honoré Champion, 1926.

9. Dvornik, Francis, Slavii în istoria şi civilizația europeană, traducere de Diana Stanciu, Bucureşti, Editura All Educațional, 2001.

10. Haldon, John F., Warfare, State and Society in the Byzantine World, 565-1204, UCL Press, London, 1999.

11. Ivanov, Sergey A., „Religious Missions”, în Jonathan Shepard (ed.), The Cambridge History of the Byzantine Empire (c. 500-1492), Cambridge, Cambridge University Press, 2008.

12. Kaplan, Michel, Bizanț, traducere din limba franceză de Ion Doru Barna, București, Editura Nemira, 2010.

13. Kazhdan, Alexander, The Notion of Byzantine Diplomacy, în Jonathan Shepard, Simon Franklin (Eds.), Byzantine Diplomacy, Aldershot, Variorum Reprints, 1992.

14. Lemerle, Paul, Istoria Bizanțului, traducere de Nicolae-Şerban Tanaşoca, Bucureşti, Editura Teora, 1998.

15. Lemerle, Paul, Istoria Bizanțului, traducerea de Nicolae ȘerbanTanaşoca, Bucureşti, Editura Teora, 1998.

16. Luttwak, Edward N., The Grand Strategy of the Byzantine Empire, Cambridge, Mass., London, The Belknap Press of Harvard University Press, 2009. 
17. Obolensky, Dimitri, Un Commonwealth medieval: Bizanțul. Europa de Răsărit, 500-1453, traducere de Claudia Dimitriu, postfață de Nicolae-Şerban Tanaşoca, Bucureşti, Editura Corint, 2002.

18. Potemkin, V. P. et alii, Istoria diplomației, vol. I, ediție a doua, revăzută şi completată, îngrijirea ştiinţifică a ediţiei româneşti: Petre Constantinescu-Iaşi, Bucureşti, Editura Ştiinţifică, 1962.

19. Setton, Keneth M., The Bulgars in the Balkans and the Occupation of Corinth in the Seventh Century, în „Speculum”, vol. 25, nr. 4,.1950.

20. Ştefan, Cristian, Misiunea creştină in Apus şi Răsărit (secolele V-X), Cluj-Napoca, Presa Universitară Clujeană, 2002.

21. Treadgold, Warren, $O$ istorie a statului şi societății bizantine, vol. I: (284-1025), traducere de Mihai-Eugen Avădanei, ediție îngrijită de Victor Spinei şi Bogdan-Petru Maleon, prefaţă de Victor Spinei, Iaşi, Institutul European, 2004. 